\title{
Vernieuwing opleiding kindergeneeskunde in de Beatrix Kinderkliniek, Universitair Medisch Centrum Groningen
}

\author{
J. Pols • E. Jippes • A.A.E. Verhagen • L.M. Hercules • \\ P. J.J. Sauer
}

Samenvatting Inleiding: De modernisering van de vervolgopleidingen bereikt in 2007 individuele opleiders: tijdens het project 'Vaart in Innovatie VervolgOpleidingen' zullen alle opleiders kindergeneeskunde en obstetrie $\&$ gynaecologie hun opleidingen aanpassen. De vraag is hoe ze de vele en complexe veranderingen zo succesvol mogelijk kunnen realiseren. Literatuurreviews laten zien dat (1) veel factoren van belang zijn, maar dat geen enkele factor onder alle omstandigheden doorslaggevend is, en (2) dat innovaties nooit lineair verlopen, maar steeds schoksgewijs. Een standaardaanpak voor succesvol veranderen is er daardoor niet en het is belangrijk om concrete ervaringen te delen. Dit artikel beschrijft de innovatie van de opleiding tot kinderarts in het opleidingscluster van de Beatrix Kinderkliniek van het Universitair Medisch Centrum Groningen.

Aanpak en resultaten: De innovatie is projectmatig aangepakt met een ontwerpfase en een implementatiefase. De ontwerpfase resulteerde na zeven maanden in 19 aanbevelingen voor de herziening van de opleiding. De implementatiefase startte begin 2003 met de ambitie om voorjaar 2004 een nieuw curriculum te starten. De start is echter uitgesteld en uiteindelijk is besloten met afzonderlijke vernieuwingen van start te gaan. Januari 2007 zijn de ontwikkelingen nog steeds gaande. Rond alle 19 aanbevelingen zijn veranderingen geheel of gedeeltelijk doorgevoerd. Er zijn ook extra ontwikkelingen geweest en de invoering van sommige vernieuwingen is opgeschort.

J. Pols $(\bowtie)$

Dr. J. Pols, arts-onderwijskundige, Wenckebach

Ontwikkelplatform.Correspondentieadres:Dr. J. Pols,

Wenckebach Ontwikkelplatform, Universitair Medisch Centrum Groningen, Postbus 30.001, 9700 RB Groningen, tel.: 050-3611609,j.pols@wenckebach.umcg.nl.Belangenconflict: geen gemeld.Financiële ondersteuning: geen gemeld.

Conclusies en beschouwing: Rond alle aanbevelingen zijn succesvol activiteiten ontplooid en de kwaliteit van de opleiding is makkelijker bespreekbaar. Vertraging trad op door (1) toenemend bewustzijn over didactische en onderwijskundige vragen, (2) landelijke moderniseringsactiviteiten en (3) een kleiner aantal aios. Retrospectief is makkelijk aan te geven wat er beter en sneller gekund had. Prospectief is wellicht de belangrijkste les dat rekening gehouden moet worden met onverwachte factoren: landelijke ontwikkelingen en onderwijskundige en didactische vragen die ontstaan door de grotere aandacht voor de opleiding. Dat alles neemt tijd en leidt tot langdurige implementatietrajecten. (Pols J, Jippes E, Verhagen AAE, Hercules LM, Sauer PJJ. Vernieuwing opleiding kindergeneeskunde in de Beatrix Kinderkliniek, Universitair Medisch Centrum Groningen. Tijdschrift voor Medisch Onderwijs 2007;26(2):63-74.)

\section{Inleiding}

De medische vervolgopleidingen veranderen in hoog tempo. ${ }^{1-4}$ De modernisering die het Centraal College Medische Specialismen (CCMS) initieerde, brengt grote inhoudelijke en onderwijskundige veranderingen met zich mee: ${ }^{1}$

1. Met de vaststelling van de algemene competenties is expliciet afgesproken dat een assistent in opleiding tot specialist (aios) zich niet alleen op het gebied van het medisch handelen, maar ook op zes andere competentiegebieden aantoonbaar moet bekwamen. ${ }^{5}$

2. Voor elke opleiding (her)formuleert men de doelen in de vorm van disciplinegebonden competenties die alle zeven competentiegebieden dekken. 
3. De opleidingen krijgen een modulaire opbouw die gerelateerd is aan de te realiseren competenties.

4. Vorm en omvang van cursorisch onderwijs worden geëxpliciteerd en de aandacht voor docentscholing wordt een verplichting.

5. Tenslotte gaan ook toetsing en beoordeling de zeven competentiegebieden bestrijken met minimaal het gebruik van Korte Praktijk Beoordelingen (KPB'S) en een portfolio. ${ }^{1}$

De meeste wetenschappelijke verenigingen zijn inmiddels bezig om de eisen die het CCMS stelt, te vertalen in nieuwe opleidingsplannen. ${ }^{1}$ Met deze opleidingsplannen stellen zij (de kaders) vast hoe de opleidingen eruit moeten zien, die alle opleiders met hun opleidingsgroepen in de dagelijkse opleidingspraktijk moeten realiseren.

De kindergeneeskunde en de obstetrie \& gynaecologie hebben inmiddels als eerste hun gemoderniseerde opleidingsplannen gepresenteerd. ${ }^{6-7}$ Om de plannen te implementeren en de opgedane ervaring te kunnen benutten voor andere disciplines, is in oktober 2006 het project In VIVO gestart: Vaart in Innovatie VervolgOpleidingen. ${ }^{8}$ Een belangrijke doelstelling van het project is het destilleren van kritische succes- en faalfactoren waar de andere opleidingen hun voordeel mee kunnen doen. Sinds de start zijn in elke onderwijs- en opleidingsregio (OOR) kernteams van opleiders en aios geformeerd die de vernieuwingen actief ter hand gaan nemen. ${ }^{4}$

De projectmatige aanpak van In VIVO gaat uit van de systematische opeenvolging van het ontwerpen van het opleidingsplan en vervolgens het stapsgewijs - top down - implementeren daarvan: eerst landelijk, dan regionaal en tenslotte lokaal. In de praktijk zal daarvan minder sprake zijn. Opleiders en opleidingsgroepen zijn lokaal al langer bezig met grotere en kleinere reorganisaties in hun opleidingen, en het inpassen van nieuwe instrumenten in de dagelijkse bedrijfsvoering en de didactische professionalisering van docenten is al jaren gaande. ${ }^{9}$ Ook in de opleiding kindergeneeskunde in de Beatrix Kinderkliniek (BKK) van het Universitair Medisch Centrum Groningen (UMCG) vinden al sinds 2002 ingrijpende veranderingen plaats. In dit artikel doen we verslag van de ervaringen die daarbij zijn opgedaan. Wat het meest opvalt is het diffuse, parallelle en niet-lineaire karakter waarmee een veelheid aan activiteiten is opgepakt. Verder zijn er vele onverwachte factoren die het innovatieproces beïnvloed hebben. De beschrijving is bruikbaar voor alle opleiders en opleidingsgroepen die willen of

\footnotetext{
${ }^{1}$ Zij krijgen daarbij advies en begeleiding van de Begeleidingsgroep Beschrijving Opleidingsplannen Vervolgopleidingen (BBOV), een door de stuurgroep Modernisering Opleidingen en Beroepsuitoefening in de Gezondheidszorg (MOBG) ingestelde begeleidingsgroep.
}

moeten innoveren. Ook de OOR-kernteams van In VIVO kunnen er hun voordeel mee doen. Voorafgaand aan de beschrijving geven we een korte toelichting op de complexiteit van het innoveren van medische vervolgopleidingen.

\section{De complexiteit van innoveren van medische vervolgopleidingen}

Hoewel alle nauw betrokkenen overtuigd zijn van de noodzaak van de veranderingen in de vervolgopleidingen, is succes bij de realisatie van de moderniseringen niet verzekerd. Niet alleen omdat er weerstand is - bijvoorbeeld van opleiders die zich afvragen of alle veranderingen wel zo noodzakelijk zijn ${ }^{10}$ - maar ook vanwege het grote aantal betrokken wetenschappelijke verenigingen en individuele opleiders en de omvang en complexiteit van de veranderingen. Waar behoefte aan bestaat, zijn handreikingen voor de succesvolle aanpak van de veranderingen, de implementatie ervan en de continuering op langere termijn. Het funderen van zo'n aanpak is daarom een van de expliciete doelen van het In VIVO-project.

Rond het CanMEDS 2000-project in Canada speelden dezelfde vragen. Het was het thema van een workshop tijdens de AMEE van 2005 die georganiseerd werd door twee belangrijke trekkers daarvan: Jason Frank en Nadia Mikhael. ${ }^{11}$ In hun workshop behandelden ze de vraag: hoe krijg ik het voor elkaar? In dat kader hadden zij de literatuur rond innoveren en veranderen bekeken en tot hun schrik vastgesteld dat er tientallen veranderkundige theorieën zijn. Die hoeveelheid alleen al wekt de indruk dat er weinig zekerheden bestaan rond de succesvolle aanpak van complexe innovaties. Een indruk die bevestigd wordt in twee literatuurreviews uit de afgelopen jaren.

In 2000 beschreven Bland et al. de factoren die samenhangen met succesvolle curriculumveranderingen. ${ }^{12} \mathrm{Om}$ daar zicht op te krijgen, bekeken zij literatuur over veranderen in het algemeen, onderwijskundige veranderingen en veranderingen in medische curricula. Uiteindelijk leverde hun zoektocht slechts 57 relevante bronnen op met daarin 35 verschillende factoren. Hoe deze factoren samenhangen en in welke mate zij de kans op succes beïnvloeden, werd uit de literatuur niet duidelijk. Opvallend was dat Bland et al. over de periode 1966-2000 slechts 25 artikelen vonden waarin expliciet werd ingegaan op het veranderingsproces van medische curricula.

In 2004 publiceerde Greenhalgh et al. het resultaat van een indrukwekkend systematisch literatuurreview over innovaties in dienstenorganisaties. Het accent van hun onderzoek lag op innoveren in de gezondheidszorg en het werd uitgevoerd in opdracht van het Britse Ministerie 
van Volksgezondheid. ${ }^{13}$ Het review heeft betrekking op 495 boeken en artikelen, en geeft naast samenvattingen ook - voor het eerst - een conceptueel model. Op basis van het review wordt daarin weergegeven welke samenhang er bestaat tussen de onderzochte determinanten die een rol spelen bij innoveren in (organisaties in) de gezondheidszorg. Twee relevante conclusies zijn:

1. Verschillen in de context (organisatie, individuen, middelen, et cetera) spelen zo'n dominante rol dat geen enkele factor onder alle omstandigheden van belang is bij succesvolle innovaties.

2. Lineair verlopende (voorspelbare) innovaties bestaan niet; het proces van idee tot inbedding in de organisatie verloopt altijd schoksgewijs, er zijn altijd tegenslagen en er zijn altijd onverwachte gebeurtenissen die de ontwikkeling beïnvloeden.

Samenvattend is over (succesvol) veranderen van medische vervolgopleidingen nog maar weinig bekend. Dat betekent helaas ook dat er maar weinig handreikingen zijn te bieden aan individuele opleiders die hun opleiding willen of moeten moderniseren, en dat recepten voor succes al helemaal ontbreken. Er is daarom alle reden tot verder onderzoek naar innovaties van vervolgopleidingen, bijvoorbeeld rond In VIVO. Tot de resultaten daarvan bekend zijn, is er ook alle reden om ervaringen rond het innoveren van vervolgopleidingen met elkaar te delen. Daarmee komen concrete voorbeelden beschikbaar die opleiders met hun eigen situatie kunnen vergelijken en waarmee zij hun voordeel kunnen doen.

\section{De casus Beatrix Kinderkliniek in Groningen}

\section{Aanleiding}

De vijfjarige opleiding tot kinderarts in het cluster van de Beatrix Kinderkliniek (BKK) van het Universitair Medisch Centrum Groningen (UMCG) kent een 'sandwichstructuur': het eerste jaar in het UMCG, het tweede jaar en het eerste deel van het derde jaar in een algemeen opleidingsziekenhuis en de laatste twee en een half jaar weer in het UMCG. Bij de opleiding zijn zes algemene opleidingsziekenhuizen betrokken. ${ }^{2}$ De jaren binnen het UMCG zijn opgedeeld in stages, waarbinnen zestien deelspecialismen een plek vinden. In het cluster zijn gemiddeld veertig assistenten in opleiding tot specialist (aios) aanwezig.

Eind 2001 werd binnen de BKK de verandering van de opleiding actueel. De aios gaven toen schriftelijk te

\footnotetext{
${ }^{2}$ Martini Ziekenhuis (Groningen), Medisch Centrum Leeuwarden, Isala Klinieken (Zwolle), Deventer Ziekenhuizen, Medisch Spectrum Twente en St. Elisabeth Hospitaal (Curaçao).
}

kennen dat de kwaliteit van hun opleiding in het gedrang kwam, doordat zij te intensief betrokken werden bij de (routine) patiëntenzorg. Ook de opleider meende dat in de loop van de tijd het evenwicht tussen opleiding en bedrijfsvoering verstoord was geraakt. Rond dezelfde tijd kwamen de landelijke discussies over de noodzaak tot modernisering van de vervolgopleidingen op gang, zo ook in de Nederlandse Vereniging voor Kindergeneeskunde (NVK). Voor de opleider was dit alles aanleiding voor een algehele analyse en herziening van de opleiding.

\section{Aanpak en tijdspad}

Het dagelijks bestuur (DB) van de BKK - waarvan de opleider deel uitmaakt - heeft opdracht gegeven voor het project Herziening Opleiding Kindergeneeskunde met daarin twee deelprojecten (figuur 1):

1. Een ontwerpfase: een analyse van de actuele situatie en het formuleren van voorstellen tot herziening.

2. Een implementatiefase: de concretisering van de herzieningsvoorstellen en de invoering van de veranderingen.

Voor de ontwerpfase is een projectgroep ingesteld. Ze rapporteerde maandelijks aan het dagelijks bestuur en in aparte bijeenkomsten - aan een klankbordgroep van kinderartsen en aios. Er is onderzocht hoe de opleiding in de BKK is beschreven en - met behulp van interviews hoe artsassistenten en opleiders de opleiding ervaren. Dit leidde tot de eerste aanbevelingen voor een herziene opleiding en een schets voor een nieuw curriculum. Definitieve aanbevelingen en een herzieningsvoorstel werden bereikt in een cyclisch proces van bijstellingen en besprekingen met de klankbordgroep en het dagelijks bestuur. De ontwerpfase duurde zeven maanden: van februari tot augustus 2002.

Voor de implementatiefase is eveneens een projectgroep samengesteld. De opdracht was om in een half jaar (januari 2003 - juli 2003) een detailontwerp te maken voor een nieuw curriculum dat voorjaar 2004 van start kon gaan. Op basis van een eerste projectplan hebben leden van de projectgroep alleen of in groepjes van twee activiteiten uitgevoerd. Gaandeweg het project is de start van het vernieuwde curriculum steeds verder uitgesteld. Uiteindelijk is besloten met afzonderlijke onderdelen van start te gaan. Het project is niet formeel beëindigd.

\section{Landelijke ontwikkelingen}

Vier landelijke ontwikkelingen rond de vervolgopleidingen hebben invloed gehad op het verloop van de implementatie. 


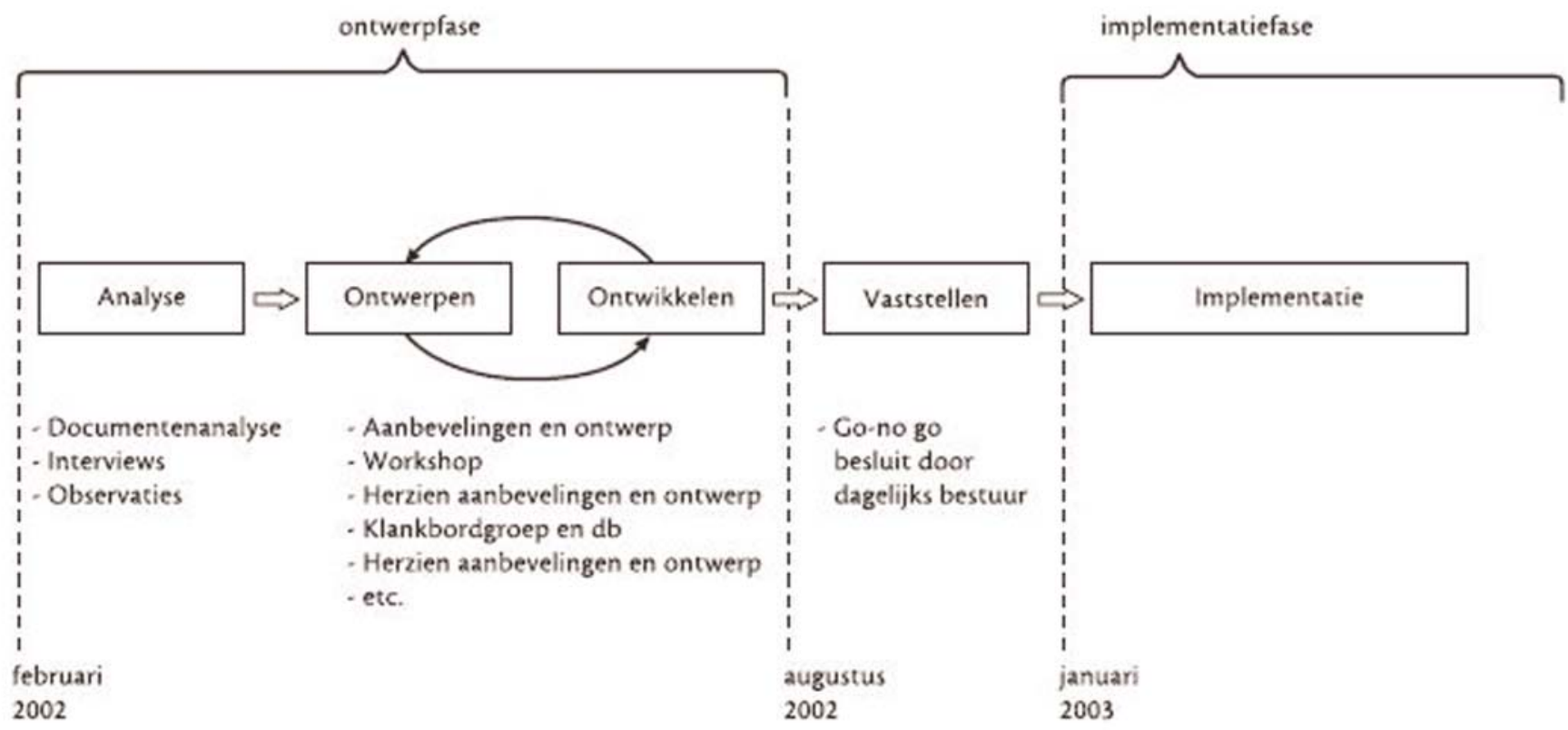

Figuur 1 Ontwerp- en implementatiefase innovatie opleiding kindergeneeskunde.

1. Medio 2003 werd duidelijk dat het CCMS voor het formuleren van algemene en disciplinegebonden competenties gebruik zou maken van het raamwerk uit het CanMEDS2000-project. ${ }^{14}$

2. In maart 2004 besloot de minister van Volksgezondheid, Welzijn en Sport onverwacht om het aantal opleidingsplaatsen voor kinderartsen te halveren. Voor de BKK betekende dit in 2004 een sterke reductie van het aantal aios en in de daaropvolgende jaren lagere aantallen dan verwacht.

3. De implementatie van de plannen van de commissie Le Grand voor de vervolgopleidingen is vanaf april 2004 voortvarend ter hand genomen door de stuurgroep Modernisering Opleidingen en Beroepsuitoefening in de Gezondheidszorg (MOBG) ${ }^{2,15}$

4. Begin 2004 startte de Nederlandse Vereniging voor Kindergeneeskunde (NVK) een project om alle opleidingen kindergeneeskunde te vernieuwen. De Stuurgroep Herziening Opleiding Kindergeneeskunde (SHOK) die deze opdracht kreeg, profiteerde graag van ervaringen en resultaten van de BKK. Een aantal leden van de projectgroep implementatiefase werd daardoor vanaf april 2004 betrokken bij het landelijke project.

\section{Resultaten ontwerpfase}

Op papier bleken er veel opleidings- en onderwijsmomenten te zijn en krijgen artsassistenten veel ruimte om zich te verdiepen in de kindergeneeskunde. Bij aios en specialisten bestond positieve waardering voor het opleidingsklimaat, de toegankelijkheid van de specialisten en de kwaliteit van de gestructureerde onderwijsmomenten. De meest genoemde bottlenecks in de opleiding waren het spanningsveld tussen de bedrijfsvoering en onderwijsmomenten, en het ontbreken van structuur.

In totaal zijn negentien (groepen van) aanbevelingen geformuleerd voor de herziening van de opleiding (zie tabel 1). Voor de concrete uitwerking van de elf belangrijkste aanbevelingen is aan het dagelijks bestuur van de BKK voorgesteld om vier deelprojecten te starten:

1. Project functieanalyse en leerdoelen: een analyse van de functie van een beginnend kinderarts en de functieonderdelen die aios in de verschillende fasen van hun opleiding moeten bereiken.

2. Project bedrijfsvoering: de realisatie van het longitudinaal volgen van poliklinische patiënten door aios, de herziening van de dienstenstructuur en een 'multi-purpose assistent' voor vervanging gedurende vakanties en ziekte.

3. Project introductieprogramma: de ontwikkeling van een introductieprogramma voor eerstejaars aios om hen voor te bereiden op hun werkzaamheden op de afdelingen en poliklinieken.

4. Project werkvormen, leermiddelen en toetsing: de uitvoering van diverse voorstellen voor cursorisch onderwijs, toetsing en docentscholing. 
Tabel 1 Plannen en resultaten bij de herziening van de opleiding kindergeneeskunde rond de Beatrix Kinderkliniek.

Project functieanalyse en leerdoelen

Resultaat*

1. Analyseer de verschillende stadia in het functieverloop \pm Functieprofiel 'jonge klare',

niet

van aios tot specialist.

2. Vertaal de functieanalyse naar leerdoelen voor de

voor functieontwikkeling aios.

\pm Voor medisch handelen, niet

voor

verschillende stages:

- Gebruik daarbij de eindtermen van het raamplan

overige algemene competenties.

kindergeneeskunde.

+ Gebruikt.

Project bedrijfsvoering

3. Laat arts-assistenten op de poli patiënten longitudinaal vervolgen.

+ In jaar 3, 4 en 5 gerealiseerd.

4. Laat diensten zo min mogelijk een onderbreking vormen van de stages.

5. Rooster arts-assistenten in voor de opvang van vakanties en

+ Laatste jaars aios vervullen deze rol.

ziekte van collegae.

\section{Project introductieprogramma}

6. Plan in de eerste stage een introductieprogramma:

- Gebruik daarbij een oriënterende entreetoets.

\pm Ontworpen maar nog niet ingevoerd.

\section{Project werkvormen, leermiddelen en toetsing}

7. Cursorisch onderwijs:

- Een keer per maand een hele dag cursorisch onderwijs.

- Maak groepen jongerjaars en ouderejaars aios met eigen leerdoelen.

- Breng een opbouw in moeilijkheidsgraad aan.

- Pas trainingen in het skillslab structureel in het onderwijs in.

\pm Er zijn afzonderlijke cursussen.

- Pas klinisch redeneren en evidence based medicine in.

+ EBM-ochtenden stafleden

en aios.

8. Introduceer feedbackgesprekken n.a.v. video-opnames van consulten.

9. Ontwikkel toetsingsinstrumenten waarmee het realiseren van

leerdoelen kan worden vastgesteld:

- Gebruik verschillende soorten toetsen.

- Ontwikkel een instrumentarium voor $360^{\circ}$ feedback.

- Volg de voortgang van aios door minimaal één toets

in elke stageperiode.

- Ontwikkel een portfolio.

10. Didactische ondersteuning van docenten:

- Docenttrainingen voor begeleiders van arts-assistenten.

\pm Training gebruik KKB en

het geven

van feedback.

- Gerichte training voor supervisoren m.b.t. communicatie

en begeleiding.

11. Ontwikkel instrumenten voor de werving en selectie van aios.

- Van afgezien.

\section{Overige aanbevelingen}

12. Houd een eerste stageperiode in het UMCG, een tweede in de periferie en een derde opnieuw in het UMCG.

13. Plan de intensive care voor grote kinderen in als vaste stage.

14. Neem stages op de polikliniek eerder en vaker op

in het opleidingstraject.

15. Maak onderscheid tussen verplichte en facultatieve 
Tabel 1 (continued)

Project functieanalyse en leerdoelen

16. Bouw de opeenvolgende stages op van eenvoudig (algemene

\pm Meer nadruk op het proces

kindergeneeskunde) naar complex (subspecialisaties).

de start en minder nadruk op de inhoud.

17. Ontwikkel per stageperiode arts-assistentklappers met o.a.

\pm Voor twee stages gerealiseerd

doelstellingen, literatuur, onderwijs- en toetsmomenten.

18. Rooster per stage een intake en vervolg- en exitgesprekken

\pm Niet structureel in elke stage. met de supervisor in.

19. Koppel in diensten jongerejaars aan ouderejaars arts-assistenten, waardoor die meer verantwoordelijkheden krijgen en leren om supervisie te verlenen.

\section{Extra ontwikkelingen}

20. Mentoraat voor jongerejaars aios.

+ Door ouderejaars aios.

21. Onderwijskundige visie op competentiegericht opleiden.

+ Visiedocument geschreven.

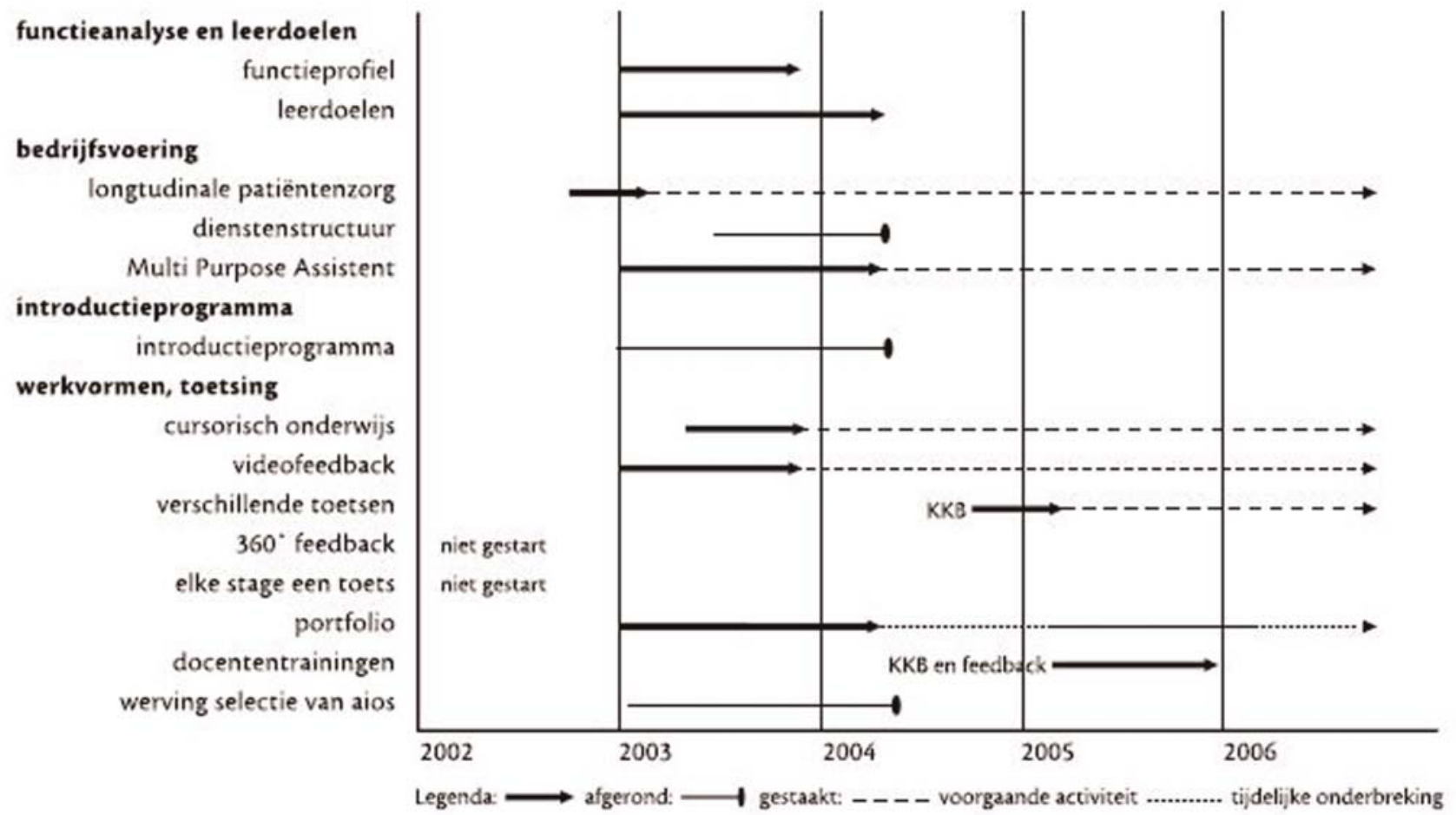

Figuur 2 Ontwikkeling en implementatie van vier deelprojecten.

Resultaten implementatietraject

figuur 2 geeft een overzicht van de gestarte activiteiten met hun doorlooptijden.

Tabel 1 geeft een samenvatting van de adviezen uit de ontwerpfase en het resultaat.

\section{Deelproject functieanalyse en leerdoelen}

Begin 2003 is een functieprofiel opgesteld voor de beginnend algemeen kinderarts. Van medio 2003 tot december 2003 is dit profiel geherformuleerd op basis van de competentiegebieden behorende bij de algemene competenties van het CCMS. ${ }^{5}$ Van medio 2003 tot mei 2004 zijn door alle (16) deelspecialismen opleidingsdoelen in de vorm van competenties beschreven. Over leerdoelen 
voor de stageperiode in algemene opleidingsklinieken zijn vanaf begin 2003 oriënterende gesprekken gevoerd. Voorjaar 2004 mondden die uit in leerdoelen voor de perifere stageperiode, die in een gezamenlijke bijeenkomst van alle opleiders werden vastgesteld.

Er is geprobeerd om voor alle competenties te onderbouwen op welke plek in de opleiding en in welke sequentie ze aan bod zouden moeten komen. Daarvoor bleken te weinig aanknopingspunten te vinden te zijn. Door de discussies ontstond wel grote behoefte om expliciet te formuleren wat competentiegericht opleiden precies betekent en waarom het nodig is. Dit leidde in april 2003 tot een notitie met een onderwijskundige visie op competentiegericht opleiden en leren binnen de BKK. De notitie is meegenomen in het opleidingsplan GOED.

\section{Deelproject bedrijfsvoering}

De continuïteit van zorg door aios in de BKK kent een onderbreking door het tweede opleidingsjaar in een algemeen opleidingsziekenhuis. De laatste drie opleidingsjaren zien zij voor langere tijd dezelfde patiënten op de polikliniek. Een eerste opzet voor de organisatie was er in oktober 2002 en werd vier maanden later ingevoerd. Stafleden en aios ervaren het als een wezenlijke en zeer positieve verandering. Het clusteren van alle diensten in één 'dienstenstage' bleek op korte termijn niet realiseerbaar. Een structurele belemmering vormt de wettelijke beperking van het aantal arbeidsuren van aios (46). Voorts vormde het relatief grote aantal zwangere aios een organisatorisch probleem. Door al deze factoren is het creëren van een dienstenstage nog niet geëffectueerd.

Om de continuïteit van de zorg bij afwezigheid van aios te waarborgen, is vanaf begin 2003 de rol van 'multipurpose assistent' ontwikkeld. De ontwikkeling en introductie bleken lastig vanwege de complexe logistiek, de vele betrokkenen (naast aios ook medisch specialisten en afdelingen) en het feit dat de veranderingen als ingrijpend werden ervaren. Sinds april 2005 draait het systeem naar tevredenheid.

\section{Deelproject introductieprogramma}

Gedurende anderhalf jaar is gewerkt aan het draaiboek voor het introductieprogramma. Toen bekend werd dat in de tweede helft van 2005 slechts twee aios zouden starten, is het programma uitgesteld tot een toename van het aantal aios, begin 2006 .

\section{Deelproject werkvormen, leermiddelen en toetsen}

Het programma van het cursorisch onderwijs is aangepast om het beter aan te laten sluiten bij de behoefte van aios in de verschillende fasen van hun opleiding. Het programma is daarvoor gesplitst in onderwijs voor jongerejaars $(=2,5$ jaar in opleiding $)$ en ouderejaars aios $(=$ 2,5 jaar in opleiding). Zowel docenten als aios zijn tevreden over de opzet.

Consulten van aios worden - met toestemming van de patiënt - op video opgenomen. Ze worden nabesproken met een kinderarts die getraind is om feedback te geven op de communicatieve vaardigheden van de aios.

Met medewerking van een studente onderwijskunde zijn doel en inhoud van een portfolio voor de kindergeneeskunde in kaart gebracht. ${ }^{16}$ In maart 2004 resulteerde dit in een eerste versie die in de periode april tot augustus 2004 werd getest. Het ontwikkelde format en de ervaringen daarmee zijn ingebracht bij de SHOK en vormen de basis voor het portfolio zoals dat door de NVK is vastgesteld. Dit portfolio werd begin 2006 in de BKK geïntroduceerd. Er is toen ook gestart met het gebruik van Korte Praktijk Beoordelingen (KPB'S). Voor de ontwikkeling van een $360^{\circ}$ feedbackinstrument bleek te weinig enthousiasme te bestaan.

Gaandeweg het implementatietraject ontstond bij stafleden van de BKK de behoefte aan verdere training om aios goed te kunnen beoordelen, feedback te kunnen geven en te begeleiden. De eerste trainingen vonden in het najaar van 2004 plaats rond het gebruik van de KPB en het geven van feedback daarbij. Diverse stafleden hebben inmiddels ook een of meer van de drie modules van het Teach-the-Teacher programma van het UMCG gevolgd..$^{9,} 17$

Bij de werving en selectie van aios zijn de opleider en de plaatsvervangend opleider uit het UMCG betrokken en vijf van de zes niet academische opleiders. ${ }^{3}$ De behoefte aan selectie-instrumenten is ontstaan door steeds oplaaiende discussies over de eisen die men aan potentiële aios moet stellen. Is bijvoorbeeld ruime ervaring in de patiëntenzorg een pré of juist het voltooid hebben van een proefschrift? Een oriëntatie op de beschikbare selectie-instrumenten en een herbezinning op de noodzaak van het gebruik daarvan leidden tot het besluit om de procedure vooralsnog niet aan te passen.

\section{Overige aanbevelingen}

Onder deze noemer waren acht aanbevelingen gedaan die niet in een project werden ondergebracht. De

\footnotetext{
${ }^{3}$ De opleider uit Curaçao kan niet altijd aanwezig zijn.
} 
verwachting was dat ze ook zonder project gerealiseerd zouden kunnen worden. Dat blijkt ook grotendeels het geval geweest te zijn (zie tabel 1).

\section{Conclusies en beschouwing}

Duidelijk is dat er de afgelopen jaren veel is veranderd in de opleiding tot kinderarts in het opleidingscluster van de Beatrix Kinderkliniek van het UMC Groningen. De kwaliteit van de opleiding staat nadrukkelijk op de agenda, veranderingsvoorstellen zijn gemakkelijk bespreekbaar en er zijn veel positieve geluiden van specialisten en aios over de opleiding. Bovendien fungeert de opleidingsregio succesvol als ontwikkelregio en proeftuin voor de Nederlandse Vereniging voor Kindergeneeskunde en hebben lokale ontwikkelingen een plek gevonden in het landelijke opleidingsplan GOED.

Van de beschreven innovatie is de ontwerpfase in z'n geheel vlot en succesvol verlopen. Bij de implementatiefase zijn diverse kanttekeningen op hun plaats. Niet alle oorspronkelijke doelen zijn (volledig) gerealiseerd, gaandeweg zijn nieuwe doelen in beeld gekomen (zie het overzicht in tabel 1 en figuur 2) en de implementatiefase duurt veel langer dan voorzien. De redenen zijn in drie groepen in te delen: landelijke ontwikkelingen, een groter bewustzijn van onderwijskundige en didactische vragen, en de aanpak van het project.

\section{Landelijke ontwikkelingen}

De modernisering van de vervolgopleidingen door het CCMS en de NVK en de beperking van de aantallen aios leidden op verschillende manieren tot aanpassingen. Rond het noodzakelijke toetsinstrumentarium ontstond bijvoorbeeld meer duidelijkheid door de eisen die het CCMS stelde.

De beschikbare energie kon daardoor gericht worden op de KPB's en het portfolio. De meeste ontwikkelingen leidden echter tot vertraging, omdat activiteiten opnieuw moesten worden uitgevoerd (herformulering van het functieprofiel binnen het raamwerk van de algemene competenties van het CCMS), tot stilstand kwamen (de daling van het aantal aios leidt tot uitstel van de start van de introductieperiode), of een ander doel kregen (de ontwikkeling van een portfolio voor de BKK werd uiteindelijk een pilot voor de NVK).

Groter bewustzijn van onderwijskundige en didactische vragen

De implementatie van de plannen voor de curriculumherziening heeft bij de betrokkenen geleid tot een groter bewustzijn van de didactische en onderwijskundige vraagstukken die er spelen. Gaandeweg rezen daardoor nieuwe vragen. Zo waren er bijvoorbeeld - in de literatuur of bij opleidingen elders - te weinig aanknopingspunten voor een beschrijving van de manier waarop competenties van aios zich in opeenvolgende stages ontwikkelen. Dat leidde tot de behoefte om antwoord te geven op de vraag wat competentiegericht opleiden is en wat dat betekent voor de opleiding van kinderartsen. Wat weer resulteerde in het schrijven van een visiedocument.

Dit en andere voorbeelden worden ervaren als positieve ontwikkelingen die deel uitmaken van de bewustere manier waarop men met de opleiding omgaat. Gezien vanuit de beoogde implementatie heeft het wel tot vertraging geleid, omdat de tijd die er voor nodig is niet was gecalculeerd en de beoogde innovaties trager verliepen dan oorspronkelijk gepland.

\section{Aanpak van het project}

Waar in de ontwerpfase een tamelijk strakke, projectmatige aanpak is gehanteerd, is die aanpak tijdens de implementatiefase alleen in het begin gevolgd. Later is ze gaandeweg overgegaan in meer diffuse, minder gestuurde en minder gestructureerde innovatieactiviteiten. De veranderingen in de landelijke context hebben daarbij zeker een rol gespeeld. Daarnaast zijn diverse andere factoren te noemen: de onderwijsontwikkeling kostte meer tijd dan voorzien, de betrokkenen werden te beperkt vrijgespeeld en secretarieel ondersteund, en het overwinnen van weerstanden bij betrokkenen kostte meer tijd dan voorzien. Al met al was het implementatieproces met veel parallelle veranderingen complexer dan voorzien.

Terugkijkend is relatief gemakkelijk aan te geven waar en hoe men de implementatiefase anders aan had kunnen pakken om het succes verder te vergroten. Wijsheid achteraf is echter wat anders dan een praktisch advies voor de aanpak van een succesvol implementatietraject. De eerder geciterede reviews van Bland en Greenalgh over innoveren en veranderen in het medisch onderwijs en in de gezondheidszorg, maken ook duidelijk dat er geen recepten voor succesvol innoveren bestaan. ${ }^{12-13}$ Daarvoor zijn complexe innovaties te veelvormig en is nog onvoldoende bekend over de manier waarop allerlei factoren het succes beïnvloeden. Wat ook een rol speelt, is dat lineair verlopende (voorspelbare) innovaties niet bestaan. ${ }^{13}$ Het proces van idee tot inbedding in de organisatie verloopt altijd schoksgewijs, er zijn steevast tegenslagen en onverwachte gebeurtenissen die de ontwikkeling beïnvloeden. Verder onderzoek naar de manier waarop succesvolle innovaties in 
vervolgopleidingen tot stand gebracht kunnen worden, is daarom noodzakelijk. Mogelijk dat het In VIVO-project hierover meer uitsluitsel kan geven.

Praktisch gezien is wellicht de belangrijkste les uit de innovatie van de opleiding kindergeneeskunde dat men rekening moet houden met de onverwachte factoren die daarbij voor vertraging zorgden: landelijke ontwikkelingen en een toenemend aantal onderwijskundige en didactische vragen. De aanpak van innovaties moet flexibel genoeg zijn om externe (landelijke, regionale, instituuts-) ontwikkelingen te kunnen incorporeren, en bij het begin moet gecalculeerd worden dat de (gevolgen van de) cultuuromslag naar meer aandacht voor de opleiding ook tijd vergt. De OOR-kernteams van In VIVO kunnen hier in ieder geval hun voordeel mee doen.

\section{Summary}

Introduction: Directors of postgraduate specialist training programmes in paediatrics and in obstetrics and gynaecology in the Netherlands are required to change their training programmes in 2007. The question is which approach to change is likely to be the most successful. Literature reviews have shown that (1) many factors contribute to successful innovations but no single factor is crucial in all situations; (2) innovation is not a linear process but moves in fits and starts. In the absence of a recipe for successful innovation it is important to share concrete experiences. This paper presents the innovation in paediatrics training in Beatrix Children's Clinic, University Medical Center Groningen.

Work done and results: A project approach was used involving a development phase and an implementation phase. The sevenmonth development phase resulted in 19 proposals for change. Starting in 2003 the implementation phase was aimed at launching the new curriculum early in 2004. The start was postponed, however, and only partial innovations were introduced. In January 2007 changes were still under way. The 19 proposals for change have been partly or fully implemented. There have been new developments too and the introduction of some innovations has been postponed.

Conclusions and discussion: Successful steps were taken in relation to all proposals. The quality of the training programme is now open to discussion. Delays were due to: (1) growing awareness of didactic and educational issues, (2) national developments and (3) declining number of trainees.In retrospect it seems easy to pinpoint what might have been done better and faster. The main lesson for the future seems to be that more attention should be paid to unforeseen factors: national developments and educational and didactic issues arising due to increased attention for training. This will take time and prolong the implementation trajectories. (Pols J, Jippes E, Verhagen AAE, Hercules LM, Sauer PJJ. Innovation in postgraduate training in paediatrics in Beatrix Children's Clinic, University Medical Center Groningen. Dutch Journal of Medical Education 2007;26(2):63- 74.)

\section{Literatuur}

Bleker OP, Hoorntje JCA, Schelfhout VJ. Beter en leuker: CCMS ontvouwt plannen voor de vervolgopleiding van medisch specialisten. Med Contact 2004;59(3):1692-5.
Crul BVM. Het is nu of nooit: Sorgdrager en Van Schilfgaarde over de modernisering van de opleiding. Med Contact 2004;59 (48):1900-2.

Stuurgroep Modernisering Opleidingen en Beroepsuitoefening in de Gezondheidszorg. Project "Modernisering Medische Vervolgopleidingen": ontwikkeling en implementatie van een vernieuwd opleidingstraject tot (medisch) specialist [projectplan]. Utrecht: Stuurgroep MOBG; 2005.

In VIVO: Vaart in Innovatie VervolgOpleidingen [projectplan]. CBOG, NFU, NVZ/STZ, Orde, NVK, NVOG, JA NVK, VAGO; augustus 2006 [geciteerd 28-12-2006]. Beschikbaar op: www.medischevervolgopleidingen. $\mathrm{nl} / /$ content/documenten/ invivo/1.pdf.

KNMG, CCMS. Algemene competenties van de medisch specialist [rapport]. Utrecht: KNMG; 2005 [geciteerd 28-2-2006]. Beschikbaar op: http://knmg. artsennet.nl/uri/?uri=AMGATE_6059_100_TICH_R158679960183152.

Opleidingsplan kindergeneeskunde: Generieke Onderwijs en Evaluatie Doelen (GOED) [geciteerd 28-12-2006]. Beschikbaar op: www.medischevervolgopleidingen. nl/pages/content/S2/ kindergeneeskunde1. aspx.

Project- en stuurgroep HOOG, editors. Curriculum opleiding tot gynaecoloog op basis van het NVOGproject Herziening Opleiding Obstetrie en Gynaecologie (NVOG-HOOG) [rapport]. NVOG, VAGO; september 2005 [geciteerd 28-12-2006]. Beschibaar op: www.medischevervolgopleidingen.nl// content/. $\mathrm{nl} / /$ content/documenten/specialisme/gynaecologie/ nvog_hoog.pdf.

Verslag startbijeenkomst In VIVO 17 oktober 2006 [geciteerd 28-12-2006]. Beschikbaar op: http://www medischevervolgopleidingen. .nl/pages/content/S2/invivo2.aspx.

Zwierstra RP, Venekamp R, Koppelman GH. Docentprofessionalisering: de stand van zaken anno 2006. Tijdschrift voor Medisch Onderwijs 2006;25(6): 279-84.

Olde Rikkert M. De valkuil van de innovatiedrang. Med Contact 2005;60(4):147-9.

Frank JR, Mikhael NZ. Implementing competency frameworks in medical education: theory and lessons from the CanMEDS project [abstract workshop 4T]. In: AMEE 2005. Abstracts. AMEE: 30 augustus-3 september 2005; Amsterdam, Nederland. Dundee: Association for Medical Education in Europe; 2005. p. 74.

Bland CJ, Starnaman S, Wersal L, Moorhead- Rosenberg L, Zonia S, Henry R. Curricular change in medical schools: how to succeed. Acad Med 2000;75(6):575-94.

Greenhalgh T, Robert G, Macfarlane F, Bate P, Kyriakidou O. Diffusion of innovations in service organizations: systematic review and recommendations. Milbank Quarterly 2004;82 (4):581-629.

Bleker OP, Plasmans CMT. Notitie modernisering [vergaderstuk]. CCMS/KB 03-209. Utrecht: KNMG/ CCMS; 2003.

LeGrand-van den Boogaard MJM, Rooijen APN van, editors. De zorg van morgen. Flexibiliteit en samenhang. Advies van de Commissie Implementatie Opleidingscontinuüm en Taakherschikking. Den Haag: Ministerie van VWS; juli 2003.

Graaf S de. Een onderzoek naar een betrouwbaar en valide portfolio voor de medisch specialistische opleiding Kindergeneeskunde in het Academisch Ziekenhuis Groningen [afstudeeronderzoek onderwijskunde]. Rijksuniversiteit Groningen: Faculteit der Pedagogische, Psychologische en Sociologische Wetenschappen; 2003.

Website Wenckebach Instituut [geciteerd 28-12- 2006]. Beschikbaar op: www.wenckebachinstituut.nl. 